\title{
Developing Wound Dressings Using 2-deoxy-D-Ribose to Induce Angiogenesis as a Backdoor Route for Stimulating the Production of Vascular Endothelial Growth Factor
}

\author{
Serkan Dikici 1,2,*D, Muhammad Yar ${ }^{3}$, Anthony J. Bullock ${ }^{2} \mathbb{D}$, Joanna Shepherd ${ }^{4}$, Sabiniano Roman ${ }^{2} \mathbb{D}$ \\ and Sheila MacNeil ${ }^{2, *}$ \\ 1 Department of Bioengineering, Izmir Institute of Technology, 35430 Izmir, Turkey \\ 2 Department of Materials Science \& Engineering, Kroto Research Institute, University of Sheffield, \\ Sheffield S3 7HQ, UK; a.j.bullock@sheffield.ac.uk (A.J.B.); s.roman@sheffield.ac.uk (S.R.) \\ 3 Interdisciplinary Research Centre in Biomedical Materials (IRCBM), COMSATS University Islamabad, \\ Lahore Campus, Lahore 54000, Pakistan; drmyar@cuilahore.edu.pk \\ 4 School of Clinical Dentistry, University of Sheffield, Sheffield S10 2TA, UK; j.shepherd@sheffield.ac.uk \\ * Correspondence: serkandikici@iyte.edu.tr (S.D.); s.macneil@sheffield.ac.uk (S.M.)
}

\section{check for} updates

Citation: Dikici, S.; Yar, M.; Bullock, A.J.; Shepherd, J.; Roman, S.; MacNeil, S. Developing Wound Dressings Using 2-deoxy-D-Ribose to Induce Angiogenesis as a Backdoor Route for Stimulating the Production of Vascular Endothelial Growth Factor. Int. J. Mol. Sci. 2021, 22, 11437. https://doi.org/10.3390/ ijms222111437

Academic Editor: John G. Hardy

Received: 29 September 2021

Accepted: 21 October 2021

Published: 23 October 2021

Publisher's Note: MDPI stays neutral with regard to jurisdictional claims in published maps and institutional affiliations.

Copyright: (c) 2021 by the authors. Licensee MDPI, Basel, Switzerland. This article is an open access article distributed under the terms and conditions of the Creative Commons Attribution (CC BY) license (https:// creativecommons.org/licenses/by/ $4.0 /)$.

\begin{abstract}
D-Ribose (2dDR) was first identified in 1930 in the structure of DNA and discovered as a degradation product of it later when the enzyme thymidine phosphorylase breaks down thymidine into thymine. In 2017, our research group explored the development of wound dressings based on the delivery of this sugar to induce angiogenesis in chronic wounds. In this review, we will survey the small volume of conflicting literature on this and related sugars, some of which are reported to be anti-angiogenic. We review the evidence of $2 \mathrm{dDR}$ having the ability to stimulate a range of pro-angiogenic activities in vitro and in a chick pro-angiogenic bioassay and to stimulate new blood vessel formation and wound healing in normal and diabetic rat models. The biological actions of $2 \mathrm{dDR}$ were found to be 80 to $100 \%$ as effective as VEGF in addition to upregulating the production of VEGF. We then demonstrated the uptake and delivery of the sugar from a range of experimental and commercial dressings. In conclusion, its pro-angiogenic properties combined with its improved stability on storage compared to VEGF, its low cost, and ease of incorporation into a range of established wound dressings make $2 \mathrm{dDR}$ an attractive alternative to VEGF for wound dressing development.
\end{abstract}

Keywords: 2-deoxy-D-Ribose (2dDR); deoxy sugar; angiogenesis; wound healing; chronic wounds; wound dressing

\section{Background to Identifying $2 \mathrm{dDR}$ as a Pro-Angiogenic Sugar}

2-deoxy-D-Ribose (2dDR) is a D-isomer of a deoxy pentose monosaccharide in which the hydroxyl group at the C-2 position is replaced by a hydrogen atom. $2 \mathrm{dDR}$ was discovered in 1930 by Phoebus Levene during his studies revealing DNA structure [1,2]. Since then, 2dDR is mostly known for its presence in DNA's nucleic acid structure and naturally occurs in the body by the enzymatic degradation of thymidine to thymine via thymidine phosphorylase (TP) [3]. Phosphorylases catalyse the addition of a phosphate group from an inorganic phosphate to an acceptor. In the body, TP plays an important role in recovering nucleosides after DNA degradation. Although the reaction is reversible, TP's function is primarily catabolic [4,5]. TP has an amino acid sequence identical to platelet-derived endothelial cell growth factor (PD-ECGF) [6,7] and, as previously stated, catalyses the phosphorylation of thymidine to thymine [8,9] and 2-deoxyribose-1-phosphate (2dDR1P). $2 \mathrm{dDR} 1 \mathrm{P}$ will then be dephosphorylated within the cytoplasm to $2 \mathrm{dDR}$, which is the form that can pass through the cell membrane. It has previously been shown that the addition of thymidine to platelets increases the levels of thymine and 2dDR but not 2dDR1P in the 
extracellular medium [4], which clearly shows that the phosphate is removed within the cytoplasm. Dephosphorylation allows the mobility of 2dDR from the cell membrane.

To understand the angiogenic potential of $2 \mathrm{dDR}$, we need to learn about the proangiogenic potential of TP first. In the late 1970s, one of the remarkable discoveries about TP and angiogenesis was that elevated TP activity was found in cancer patients compared to controls [10]. Judah Folkman, a pioneer in the field of cancer angiogenesis, suggested that tumour growth is angiogenesis dependent [11], which explains why cancer patients showed increased TP and angiogenic activity.

In the early 1990s, TP was identified to have an identical sequence to PD-ECGF [6,7]. The angiogenic activity of TP is known to be dependent upon its enzymatic activity but research at the time could not explain its molecular mechanism. There were two popular opinions on why endothelial cells (ECs) were attracted (as an indicator of angiogenesis) to an area with TP enzyme activity; (i) the substrate (thymidine) for the enzymatic reaction or (ii) the side products were chemoattractant to ECs [12-14]. Since exogenous treatment of thymidine was not been found to have a positive effect on ECs, the latter option, catalytic production of $2 \mathrm{dDR}$, as a side product of this enzyme activity, was considered to be the most promising reason for TP's pro-angiogenic activity [5,15-17]. A few groups demonstrated a positive impact on proliferation and migration of ECs in response to $2 \mathrm{dDR}$ treatment $[16,17]$.

Several groups then explored the effect of $2 \mathrm{dDR}$ at cellular and molecular levels in vitro. Essentially, 2dDR was shown to induce tubulogenesis $[18,19]$, inhibit hypoxiainduced apoptosis [20], and increase VEGF and IL-8 production [21] of ECs in vitro supporting the early reports of $2 \mathrm{dDR}$ 's positive impact on proliferation and cell migration. All of these studies contributed significantly to describe the potential of $2 \mathrm{dDR}$ to be used in the world of pro-angiogenic drugs. However, none of these studies went beyond in vitro experiments and there was no attempt to establish any dose-dependent activity.

In 2017, our group became the first to investigate 2dDRs pro-angiogenic potential in a chick chorioallantoic membrane (CAM) bioassay, a useful in vivo assay that is approved by the U.S. Food and Drug Administration (FDA) for the pre-clinical evaluation of products for the management of chronic cutaneous ulcer and burn wounds [22] and widely used in angiogenesis studies [23-28], and also its effect on wound healing using a full-thickness skin wound in rats [29]. Dikici et al. demonstrated the dose-dependence of 2dDR and defined its active concentration range in the CAM bioassay [30] and on human aortic endothelial cells (HAECs) [31]. After determining an effective and safe dose range, several wound dressing products (the details of these products will be given in Section 5) were developed. These delivery vehicles were chitosan/collagen [29], Poly(3-hydroxybutyrateco-3-hydroxyvalerate) (PHBV) [30], alginate [32,33], cotton fibres and cotton fibres that are coated with wax to reduce adhesion to wounds [34]. All of these studies clearly demonstrated that $2 \mathrm{dDR}$ is a pro-angiogenic deoxy sugar that can be easily introduced into a variety of biomaterials not only to stimulate angiogenesis but also to accelerate wound healing even in diabetic chronic wounds.

Figure 1 summarises the key milestones during the exploration of TP and $2 \mathrm{dDR}$ as potential pro-angiogenic agents. 


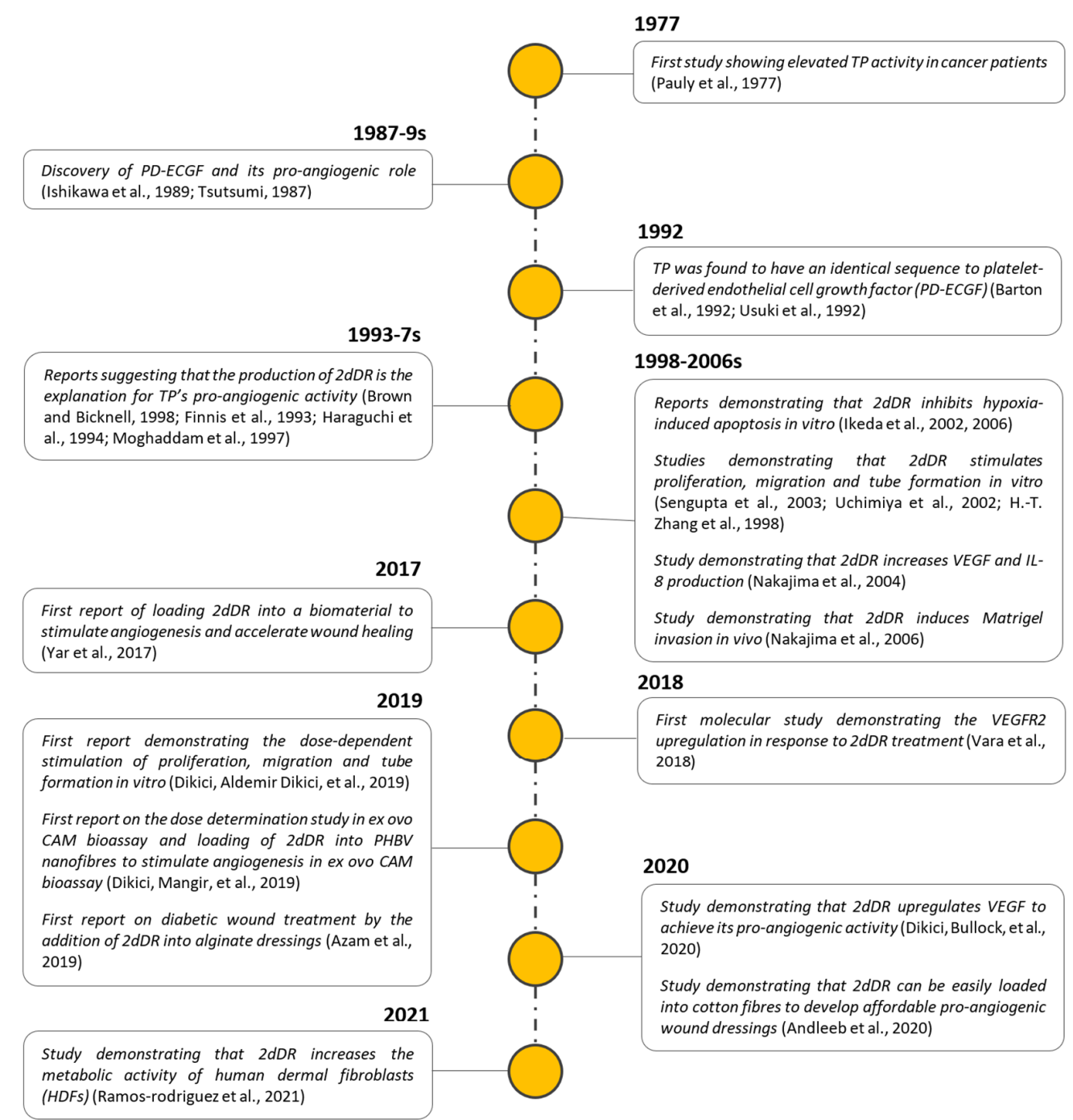

Figure 1. Key milestones of the exploration of 2dDR's pro-angiogenic activity.

To date, relatively few groups have explored 2dDR's potential in the field of angiogenesis promoters as explained above. Thus, the literature on the angiogenic activity of $2 \mathrm{dDR}$ is not very comprehensive. Accordingly, the Web of Science (WoS) and PubMed databases were screened for articles in which 2dDR, TP and VEGF were studied for their angiogenic activity. Data were generated using "pro-angiogenic agent name (i.e., 2-deoxy-D-Ribose)" and "angiogenesis" as search terms. In the WoS database, only 27 studies were found studying the potential angiogenic effect of 2dDR to date, whereas there were 696 and 43603 studies on the angiogenic activity of TP and VEGF, respectively. Similarly, in PubMed database, there were 25 publications in which $2 \mathrm{dDR}$ was considered as a pro-angiogenic agent, whereas 463 and 43,517 studies were conducted on the pro-angiogenic activity of TP and VEGF, respectively.

The distribution of these publications over the years in the WoS and PubMed databases from 1990 to the current time is given in Figure 2. 

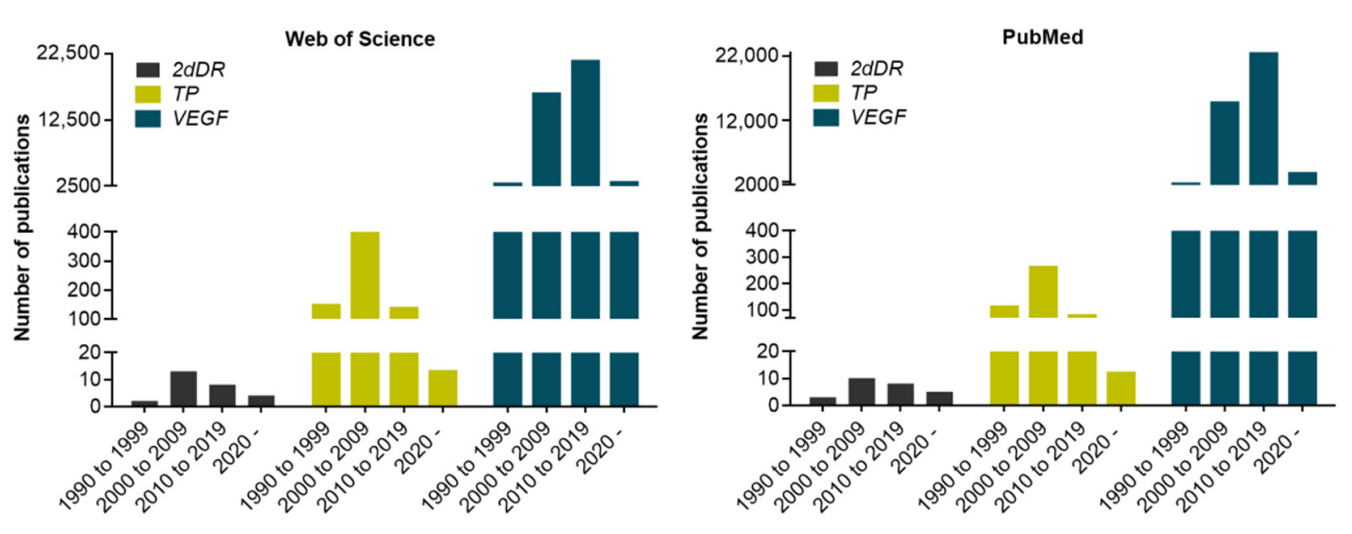

Figure 2. Distribution of angiogenesis-related publications using the WoS and PubMed databases on 2dDR, TP and VEGF from 1990 to date.

\section{Exploration of the Dose-Dependent Biological Activity of 2dDR}

Although a few groups have previously shown biological activity of $2 \mathrm{dDR}$ using in vitro models and in vivo models, a single dose or a maximum of two doses were selected in these studies. In 2019, Dikici et al. reported a dose-dependent response to 2dDR treatment.

In 1994, Haraguchi et al. reported that both 10 and $100 \mu \mathrm{M}$ of $2 \mathrm{dDR}$ act as a chemoattractant to bovine aortic endothelial cells (BAE) on a fibronectin matrix, and a $50 \mathrm{pmol}$ dose of 2dDR stimulates angiogenesis in the CAM bioassay [35].

In 1998, Zhang et al. reported that 2dDR, but not the enantiomer 2-deoxy-L-ribose (2dLR), stimulates the migratory response of microvascular endothelial cells (HMEC-1) using a Boyden chamber assay [36]

In 2002, Uchimiya et al. showed that both 10 and $100 \mu \mathrm{M}$ of $2 \mathrm{dDR}$ stimulate migration of BAE in a modified Chemotaxicell chamber assay, and $10 \mu \mathrm{M}$ of $2 \mathrm{dDR}$ enhances tube formation of BAE seeded on a type I collagen gel [18].

In 2003, Sengupta et al. demonstrated that 2dDR induces tube formation of human umbilical vein endothelial cells (HUVECs) at $1 \mu \mathrm{M}$ concentration, using an AngioKit ${ }^{\mathrm{TM}}$ coculture system, and both 0.1 and $10 \mu \mathrm{M}$ doses of $2 \mathrm{dDR}$ have a positive impact on the proliferation of HUVECs in a stretch wound healing assay. In addition to these in vitro results, they also showed increased an angiogenic activity in response to $2 \mathrm{nmol}$ of $2 \mathrm{dDR}$ treatment in a sponge granuloma model [17].

In 2004, Nakajima et al. reported that $100 \mu \mathrm{M}$ of 2dDR increases VEGF and interleukin8 (IL-8) mRNA expressions in a human epidermoid carcinoma cell line (KB) under hypoxic conditions [21].

In 2006, Nakajima et al. demonstrated that $100 \mu \mathrm{M}$ 2dDR increases the secretion and activity of matrix metalloprotease-9 (MMP-9) of human epidermoid carcinoma cells (KB cells) and upregulates the invasive behaviour of KB cells in a Matrigel invasion assay, where Matrigel serves as a reconstituted basement membrane for cells to degrade and invade [37].

In 2017, Yar et al. showed that $1 \mathrm{mg} / \mathrm{mL} 2 \mathrm{dDR}$ loaded into chitosan (CS)/collagen hydrogel promotes angiogenesis in the CAM bioassay and accelerates healing of cutaneous wounds in rats [29].

In 2018, Vara et al. reported that a $8 \mu \mathrm{M}$ to $1 \mathrm{mM}$ range of $2 \mathrm{dDR}$ upregulates VEGFreceptor 2 (VEGFR2) in HUVECs by activating NADPH Oxidase 2 (NOX2) and triggers Nuclear Factor Kappa B-dependent angiogenesis [38].

In 2019, Dikici et al. conducted a dose-dependent study of 2dDR in vitro. In this study, a range of 5 concentrations from $10 \mu \mathrm{M}$ to $1 \mathrm{mM}$ of $2 \mathrm{dDR}$ increased the metabolic activity and proliferation (assessed using resazurin reduction assay) and migratory response (assessed using a modified Boyden chamber assay) of HAECs. $100 \mu \mathrm{M}$ of $2 \mathrm{dDR}$ was also found to stimulate tube formation (assessed using a Matrigel tube formation assay) of HAECs while $1 \mu \mathrm{M}$ was ineffective and $10 \mathrm{mM}$ showed toxic effects on these cells [31,39]. 
In 2019, Dikici et al. investigated the direct administration of 3 different doses of $2 \mathrm{dDR}$ into an ex ovo CAM bioassay. In this study, 20 and $200 \mu \mathrm{g} /$ day/embryo applications of $2 \mathrm{dDR}$ induced angiogenesis, while $1000 \mu \mathrm{g} /$ day/embryo dose was ineffective. In addition, $1 \mathrm{~g}$ PHBV dressings loaded with 250 and $500 \mathrm{mg}$ of $2 \mathrm{dDR}$ showed significantly increased angiogenesis in the area of implantation of the dressing on the CAM [30].

In 2019, Azam et al. assessed the healing of skin wounds in vivo with commercially available alginate dressings containing $5 \%$ and $10 \%(w / v)$ of $2 \mathrm{dDR}$ using a diabetic rat wound healing model [33]. Both concentrations of $2 \mathrm{dDR}$ stimulated wound healing to a greater extent than the alginate dressing on its own.

In 2020, Andleeb et al. reported that loading of $5 \%(w / v)$ of $2 \mathrm{dDR}$ into cotton fibre dressings and into cotton-wax dressings stimulated angiogenesis in a CAM bioassay [34]. Cotton fibre dressings, a very commonly used dressing used worldwide, were used on their own to absorb exudate and coated with wax to reduce adhesion to wounds, such as in burns injuries.

In 2020, Dikici et al. showed that direct addition of $10 \mu \mathrm{M}$ and $1 \mathrm{mM}$ doses of $2 \mathrm{dDR}$ and the release of $2 \mathrm{dDR}$ from alginate dressings (10\% $(w / v) 2 \mathrm{dDR}$ per alginate dressing) into the growth media increased VEGF production from HAECs (evaluated using Human VEGF ELISA MAXTM Deluxe Set) [32].

In 2021, Ramos-Rodriguez et al. demonstrated that 50 to $1000 \mu \mathrm{M}$ of $2 \mathrm{dDR}$ added directly to the culture media increased the metabolic activity of human dermal fibroblasts (HDFs) over 6 days (assessed by resazurin reduction assay) [40].

To sum up, from the 1990s to now, relatively few groups have explored 2dDR's proangiogenic potential. Thus, the literature is not very comprehensive and until 2019, there were no studies conducted to establish a dose-dependent response to 2dDR. Research from the MacNeil/Yar groups demonstrated the effective doses of 2dDR using established in vitro and in vivo assays. However, the mechanism of action of $2 \mathrm{dDR}$ has not been clarified completely. Current data suggest that 2dDR triggers upregulation of VEGF production but further studies are needed to get a full picture in this area as will be discussed shortly.

\section{What Do We Understand of the Mechanism of Action of 2dDR? How Does Sugar Structure Affect Function?}

In peptide biology, it is well understood that not only molecular composition but 3D structural architecture to a large extent dictate function usually by interaction with receptors of precise $3 \mathrm{D}$ conformation. Unlike proteins, carbohydrates can take on several conformations depending on surrounding solvents and temperature. Before reviewing the published often contradictory literature on the pro-and anti-angiogenic effects of several sugars close to $2 \mathrm{dDR}$ we present a summary of the current understanding of the conformations of how $2 \mathrm{dDR}$ and related small sugars can be found.

\section{Isomers and Conformational Structures of Deoxyribose}

In an aqueous solution, deoxyribose exists as a tautomer of 3 anomers-a 5 membered ring deoxyribofuranose, a 6 membered ring deoxyribopyranose form and an intermediate chain form-described by Lemieux [41]. The relative amounts of each form are dependent on the solvent and temperature. In an aqueous solution at room temperature, this is $75 \%$ deoxyribofuranose, $25 \%$ deoxyribopyranose, and $0.7 \%$ chain form (Figure $3 \mathrm{~A}$ ). 


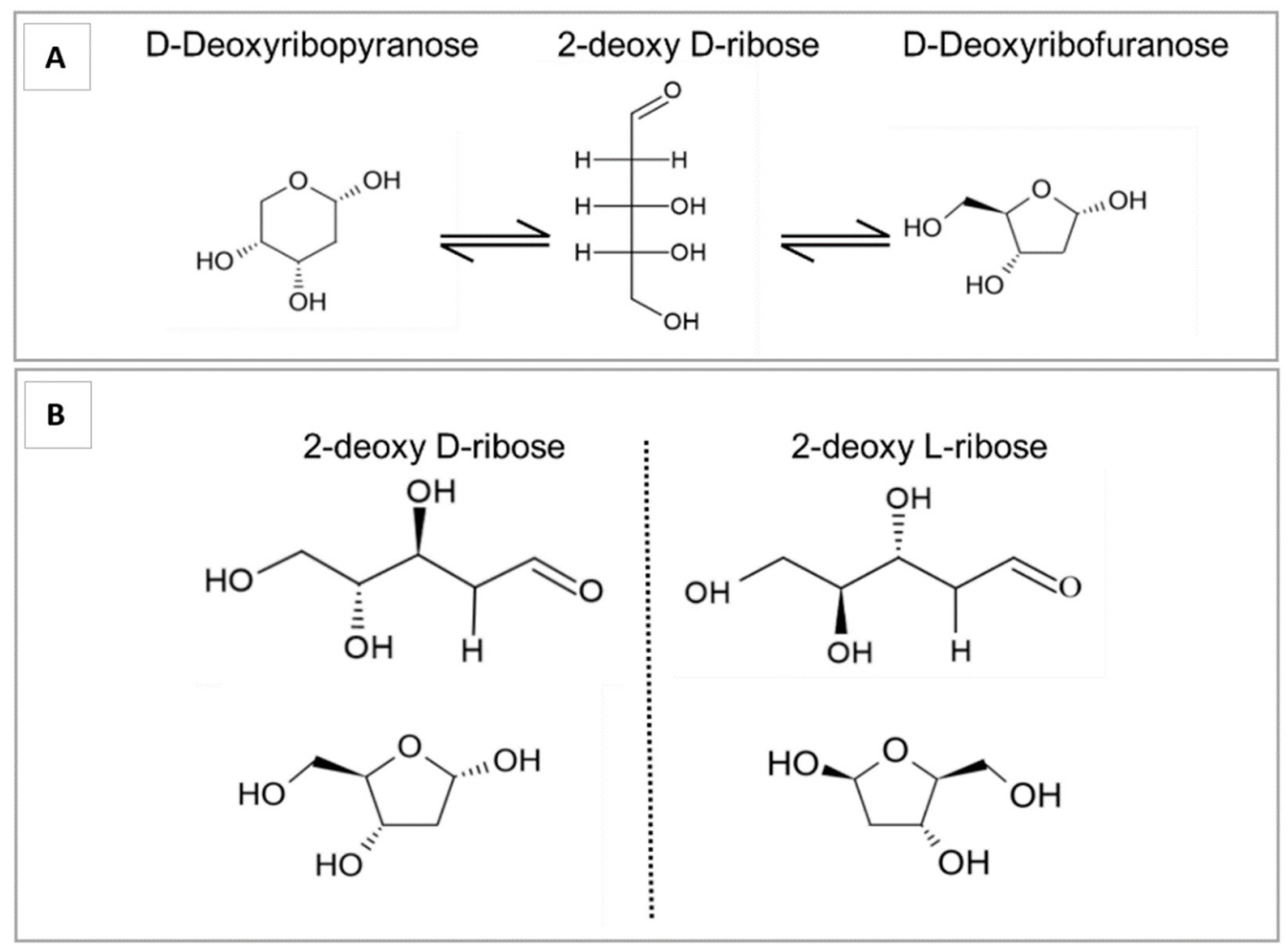

Figure 3. (A) Tautomeric forms of $2 \mathrm{dDR}$ in aqueous solution. 2dDR can exist as deoxyribofuranose, deoxyribopyranose and an intermediate chain form. (B) Stereoisomers of 2-deoxyribose. The asymmetric chiral carbon at position 2 leads to the existence of $\mathrm{D}$ and $\mathrm{L}$ isomers.

Deoxyribose is also an enantiomer, existing in two stereoisomers, the biologically active D-form, and the rarer L-form. Like the D-form, the L-form exists in solution as furanose, pyranose, and chain forms (Figure 3B). While they have the same chemical formula and the same physical properties, their interactions with other chemical groups, proteins and enzymes differ.

The D-form is a structural component of DNA, the lack of a $2^{\prime}$ hydroxyl group lending the structure conformational flexibility (compared to ribose in RNA) and allowing the formation of the double helix. 2dDR has been shown to be biologically active in the promotion of VEGF-mediated angiogenesis although it is not clear which form of the D-anomers of $2 \mathrm{dDR}$ is the biologically active form responsible for the angiogenic activity.

The biological inactivity of the L-form lends itself to the study of inhibition of 2dDRmediated functions, for example, the L-form inhibits the protection afforded by $2 \mathrm{dDR}$ against hypoxic-mediated apoptosis via interaction with thymidine phosphorylase [37]. While the D-form of $2 \mathrm{dDR}$ is a precursor for DNA synthesis, the L-form is used to create L-DNA (mirror DNA), which can store information identical to normal DNA but is resistant to biodegradation [42].

\section{Pro- and Anti-Angiogenic Activity of Small Sugars}

In contrast to the literature on the pro-angiogenic effects of $2 \mathrm{dDR}$, the reports on other small sugars are very mixed as detailed below.

$D$-glucose (DG): There are conflicting reports demonstrating the pro- and anti-angiogenic properties of DG in the literature. In 1993, Vogel et al. studied the migration of bovine corneal endothelial cells (BCE) in response to several small sugars using a modified Boyden chamber assay and reported migration toward DG (44-88 mM) [43]. Similarly, in 1999, Shigematsu et al. reported that 7-23.7 mM doses of DG stimulated migration and tube formation of HUVECs [44]. In 2016, Madonna et al. suggested that high glucose (30.5-50.5 mM) induces cyclooxygenase (COX-2) expression and the migration (assessed by CytoSelect ${ }^{\mathrm{TM}}$ cell migra- 
tion assay) and tube formation (assessed by Matrigel tube formation assay) capability of HAECs [45]. In contrast to these positive reports, in 1999, Teixeira et al. demonstrated that daily injections of $22 \mathrm{mM}$ of DG inhibited angiogenesis in the rat sponge model [46]. Similarly, in 2012, Jiraritthamrong et al. showed that 10.4-16.2 mM concentrations of DG inhibited the vessel-forming capacity of cultured endothelial progenitor cells (EPCs) using a Matrigel tube formation assay [47].

2-deoxy-L-Ribose (2dLR): The literature on 2dLR is also contradictory. In 2002, Uchimiya et al. reported that $100 \mu \mathrm{M} 2 \mathrm{dLR}$ could reduce the migratory response (assessed using Chemotaxicell chambers) and tubulogenesis (on type I collagen gel) of BAE, and $200 \mathrm{ng}$ of $2 \mathrm{dLR}$ inhibits TP-induced angiogenesis in a rat corneal assay [18]. Ikeda et al. showed that 10-50 $\mu \mathrm{M}$ doses of 2dLR promoted hypoxia-induced apoptosis of HL-60 cells [48]. Nakajima et al. reported that 10-100 $\mu \mathrm{M}$ of 2dLR inhibits both mRNA levels and secretion of IL- 8 and VEGF by KB cells [21] and $100 \mu \mathrm{M}$ 2dLR inhibits Matrigel invasion of tumours by suppressing MMP-9 in nude mice [37]. Although all these studies are consistent on the anti-angiogenic activity of 2dLR, in 2003, Sengupta et al. also suggested that $2 \mathrm{nmol}$ of $2 \mathrm{dLR}$ promotes an angiogenic response in a sponge granuloma model of angiogenesis [17]. Similarly, Yar et al. demonstrated the promotion of angiogenesis by the release of 2dLR (1 mg/mL) from chitosan/collagen hydrogels in a CAM bioassay [29].

2-deoxy-D-Glucose (2dDG): Reports on 2dDG are quite consistent in its anti-angiogenic activity. In 2008, Tagg et al. showed that 1-100 mM of 2dDG inhibited the proliferation of MCF-7 (breast) and LNCaP (prostate) cancer cell lines, and $3 \mathrm{mM} 2 \mathrm{dDG}$ reduced ATP levels [49]. In 2010, Merchan et al. reported the inhibition of proliferation, migration and tube formation capability of HUVECs by 0.06 to $6 \mathrm{mM}$ doses of $2 \mathrm{dDG}$ which also inhibited angiogenesis in vivo when administered a concentration of $6 \mathrm{mM}$ (assessed by Matrigel plug assay) [50]. In 2015, Chuang et al. demonstrated that 0.05 to $1 \mathrm{mM}$ doses of $2 \mathrm{dDG}$ inhibited the tube formation (on ECMatrix ${ }^{\mathrm{TM}}$ coated well plates) of both HUVECs in vitro and in rat aortic rings. 2dDG (0.1 to $1 \mathrm{mM})$ also reduced cell invasion and migration in HUVECs as well as the mRNA and protein expression of MMP-2 [51]. In 2016, Kovacs et al. reported the downregulation of AKT and ERK pathways and inhibition of tube formation (assessed by Matrigel tube formation assay) of Human microvascular endothelial cells from lung (HMVEC-L) in response to $0.6 \mathrm{mM}$ 2dDG [52]. In 2016, Zhang et al. demonstrated that $2 \mathrm{dDG}$ has a negative impact on proliferation $(2.5-40 \mathrm{mM}$ doses-assessed by Cell Counting Kit- 8 assay) and migration ( $5 \mathrm{mM}$ dose-assessed by Transwell Permeable Supports) of two colorectal cancer cell lines (HCT116, LoVo) [53]. In 2019, Singh et al. showed that 0.625 to $25 \mathrm{mM}$ doses of $2 \mathrm{dDG}$ impaired the metabolic viability (assessed by MTT), migration (assessed by scratch assay) and tube formation (assessed by Matrigel tube formation assay) ability of HUVECs, and Matrigel plugs loaded with $0.2 \%$ and $0.4 \%(w / v)$ of $2 \mathrm{dDG}$ significantly reduced neovascularisation when implanted into the C57BL/6 mice [54].

In summary, DG is reported to have both pro-and anti-angiogenic activity, 2dDG is consistently reported to be anti-angiogenic and $2 \mathrm{dLR}$ has reports of both pro-and anti-angiogenic activity. As $2 \mathrm{dDR}$ is predominantly pro-angiogenic, we suggest that it is challenging to draw any simple relationship between sugar structure and angiogenic activity.

\section{Developing Dressings Containing 2dDR to Stimulate Angiogenesis}

In addition to the studies to demonstrate the pro-angiogenic properties of $2 \mathrm{dDR}$, in recent years, a considerable progress has been made in developing dressings to stimulate angiogenesis by loading $2 \mathrm{dDR}$ into a range of carriers.

There have been decades of work developing dressings to stimulate angiogenesis to accelerate wound healing, particularly in those wounds which are slow to heal. Predominantly such wounds are found in the elderly or in those with diabetes, which compromises the development of small blood vessels which play a major role in wound healing [27].

As expected, there are a wealth of studies seeking to deliver well-known pro-angiogenic stimulators such as VEGF or PDGF or more recently, in work from our own and many 
other laboratories, delivering heparin which can act to bind local pro-angiogenic growth factors [55,56].

Increasingly questions have moved from "Do these work "to "Do these work sufficiently at a production cost, which makes them clinically attractive".

In treating chronic wounds which may persist for many months key questions which need to be asked are "is this safe?", "does it have any adverse effects on healing?", "does it deliver significant clinical benefit to the rate of wound healing?", "is it convenient to use for the patient and the wound care nurse?", "is it economically attractive compared to other established wound care dressings?".

As an example, there are many studies that show that local delivery of VEGF can stimulate wound healing, but this peptide is relatively unstable and dressings need to be applied at frequent intervals. Delivery of this peptide is expensive and dressings must be stored appropriately before use. Many published studies show a potential clinical benefit but have not been translated into dressings taken up for routine use.

One exception is the hydrogel product containing PDGF-Becaplermin, which is used in some diabetic foot ulcer clinics. It has a modest stimulatory effect on wound healing but can be easily stored in the fridge.

Pharmaceutical companies vigorously pursued the development of dressings delivering VEGF but these have not become routinely adopted in the clinic.

Mindful of this background, we were attracted to explore the development of dressings releasing $2 \mathrm{dDR}$, as they offered the potential for an effective, safe and conveniently used dressing for wound care. A conventional wound dressing should create a temporary protective barrier, absorb wound exudate, and preserve a moist environment to support reepithelialisation $[33,34,57]$. Conventional, inexpensive, and highly absorbent dressings for treating simple wounds do not participate actively in the healing process [57]. However, the management of deep and chronic wounds that fail to progress through the physiological healing process in a timely manner requires bioactive dressings that promote wound healing $[58,59]$.

Accordingly, our group have explored the addition of $2 \mathrm{dDR}$ to simple dressing materials as an affordable and effective way of developing bioactive dressings. The dressings our group have explored to date are summarised below.

Chitosan/collagen hydrogels: Yar et al. developed 2dDR-releasing CS/collagen hydrogels that were crosslinked by using $4 \%$ triethyl orthoformate and loaded with $1 \mathrm{mg} / \mathrm{mL}$ of $2 \mathrm{dDR}$. They confirmed the success of $2 \mathrm{dDR}$ loading via Fourier Transform Infrared Spectroscopy (FTIR). 2dDR-releasing CS/chitosan gels promoted angiogenesis in the CAM bioassay within 7 days, and accelerated the healing of wounds in a rat model in 17 days, whereas untreated and control gel-implanted wounds remained unhealed (Figure 4A,B). Immunohistochemistry analysis of wounds treated with $2 \mathrm{dDR}$ showed a good level of neovascularisation assessed by staining for ECs using a CD34 antibody. In addition, CD80 (against M1 macrophages) and CD163 (against M2 macrophages) immunostaining showed a slight dominance of M2 macrophages activity compared to M1 on day 17, as an indication of constructive remodelling and a lower inflammatory response, when the wounds were treated with 2dDR-loaded dressings [29]. 


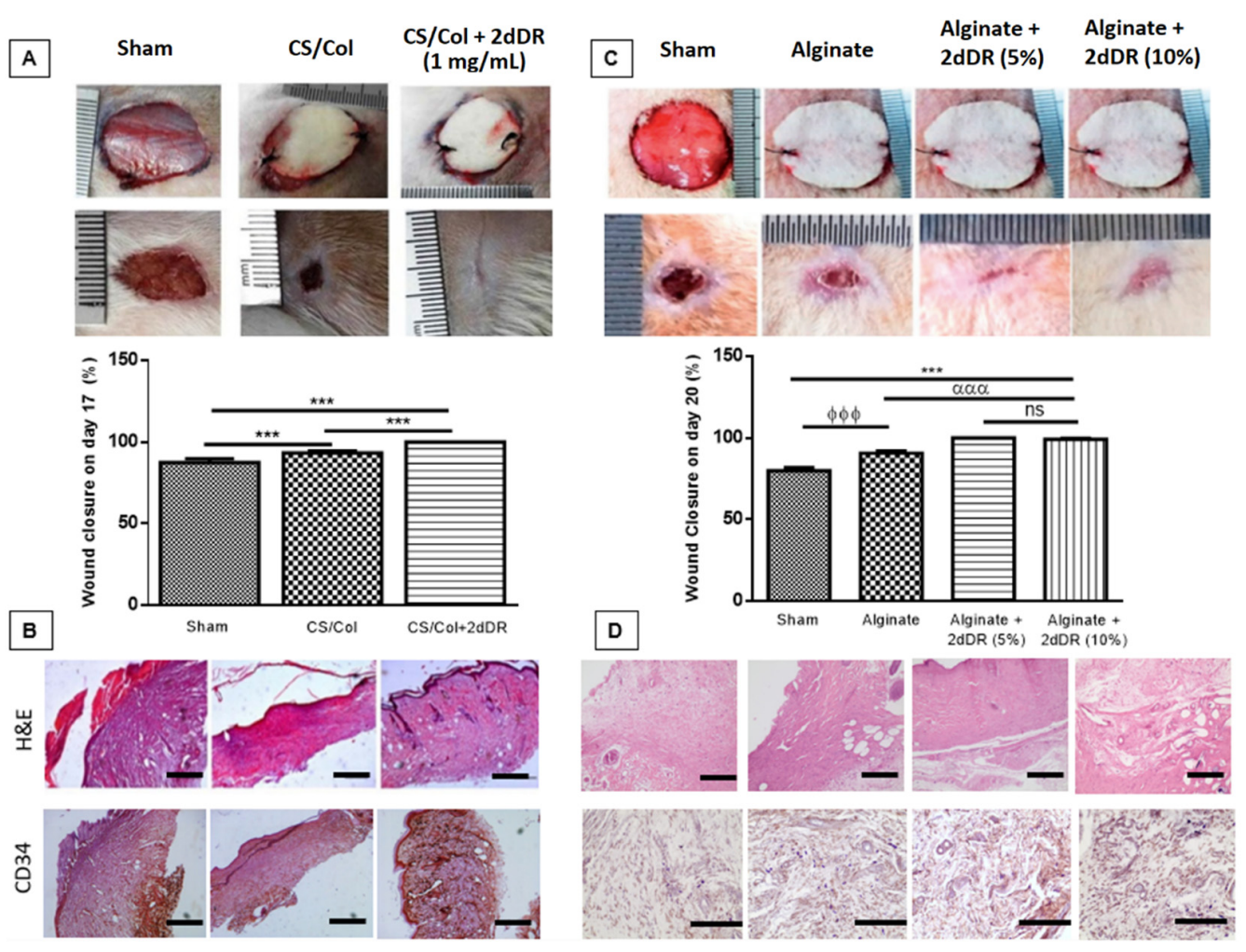

Figure 4. Gross, histological and graphical representation of wound closure analysis of animal studies. (A) Macroscopic analysis and (B) H\&E staining and immunostaining with CD34 marker of the wounds showing the healing of cutaneous wounds in 17 days when treated with 2dDR-loaded CS/Collagen hydrogels $(n=3)$. (C) Macroscopic analysis and (D) H\&E staining and immunostaining with CD34 marker showing the healing of diabetic wounds in 20 days when treated with 2dDRloaded alginate dressings $(\mathrm{n}=4)$. Scale bars represent $100 \mu \mathrm{m}$. Results are presented as mean $\pm \mathrm{SD}$ where ${ }^{* * *} p<0.001, \phi \phi \phi p<0.001, \alpha \alpha \alpha p<0.001$, ns $p>0.05$ (not significant). Images, used in (A,B), are adapted from [29] with permission granted by Materials Today Communications, Copyright 2017 Elsevier. Images, used in (C,D), are adapted from [33] with permission granted by Journal of Biomaterials Applications, Copyright 2019 Sage Publications.

PHBV fibres: In 2019, Dikici et al. loaded 250 and $500 \mathrm{mg}$ of 2dDR into $1 \mathrm{~g}$ of PHBV dressings and showed its release over 30 days using ultraviolet (UV) spectrophotometry at $238 \mathrm{~nm}$ wavelength. Approximately $90 \%$ of the $2 \mathrm{dDR}$ was found to be released from PHBV fibres within 3 days and stimulated angiogenesis in the ex ovo CAM bioassay [30].

Alginate dressings: Azam et al. incorporated 5\% or 10\% (w/v) of 2dDR into commercially available alginate dressings and showed that almost all $2 \mathrm{dDR}$ was released in 3 days. They reported that these $2 \mathrm{dDR}$-releasing alginate dressings facilitated healing of chronic wounds in 20 days using a diabetic rat wound healing model [33] (Figure 4C,D). Both concentrations of sugar were equally effective in support of these findings, in 2020, Dikici et al. showed that 2dDR-releasing alginate dressings stimulated VEGF production of HAECs in 7 days [32].

Cotton-wax dressings: Andleeb et al. used the $5 \%$ loading concentration of $2 \mathrm{dDR}$ to develop accessible and affordable pro-angiogenic dressings. In this study, two different carrier dressings were tested; a non-woven cotton dressing which is highly absorbent, designed to absorb excessive exudate absorption, and relatively less sticky to wounds; and a wax coated cotton dressing which is frequently used as first aid treatment for burn wounds. They reported several methodologies to optimise the release of $2 \mathrm{dDR}$ at an effective concentration range from both of these non-woven and wax-coated cotton dressings, and demonstrated that 5\% 2dDR-loaded cotton-wax and non-woven dressings induced neovascularisation in the CAM bioassay [34]. 


\section{Understanding the Mechanism of Action of 2dDR}

In contrast to VEGF, to date, only a limited number of groups have studied the mechanism behind the pro-angiogenic activity of $2 \mathrm{dDR}$.

In the 2000s, researchers proposed a potential mechanism that is based on the induction of oxidative stress due to the endogenous generation of $2 \mathrm{dDR}$ by TP activity which catalyses the degradation of thymidine to thymine. This has been considered as a potential way to stimulate the production and secretion of several pro-angiogenic signal proteins and chemokines such as VEGF and IL-8. They were thought to be internalised by the ECs to trigger the pro-angiogenic cascade $[17,19,60]$.

In 2018, Vara et al. approached this question from a different angle and investigated the upregulation of VEGFR2 in response to 2dDR treatment. They suggested that (i) the 2dDR-1-phosphate (2dDRP) could be produced endogenously by cells that have been shown to have TP activity (i.e., macrophages, platelets and cancer cells) and then secreted to the extracellular environment or (ii) TP might be released from cells due to the disruption of the cell membrane (injuries) to act extracellularly on the degradation of thymidine to thymine and generation of $2 \mathrm{dDR}$ extracellularly. After one of the two suggested production mechanisms, $2 \mathrm{dDR}$ can be taken up by ECs and activates NOX2 that will act on NF- $\mathrm{kB}$ to upregulate VEGFR2. Their results demonstrated that 2dDR drives VEGF-dependent angiogenesis via upregulation of VEGFR2 on the cell membrane [38].

In 2020, our group set up an experiment to evaluate whether $2 \mathrm{dDR}$ could potentially increase the production of VEGF by the ECs. In this study, HEACs were treated with several doses of $2 \mathrm{dDR}$, and VEGF in the growth media was quantified. Our results showed that $2 \mathrm{dDR}$ was the only sugar that increased VEGF production. Other small sugars including DG and 2dLR did not promote the production of VEGF by HAECs [32].

To the best of our knowledge, 2dDR achieves its pro-angiogenic activity via VEGFdependent angiogenesis. This knowledge is particularly important with respect to clinical translation of the 2dDR-releasing pro-angiogenic wound dressings, since exogenous use of VEGF in an uncontrolled manner raises safety concerns for the production of large leaky blood vessels such as are observed in tumour angiogenesis [60-63]. Regarding the structure-activity relationship, our knowledge on why 2dDR is the only sugar that stimulates VEGF production of ECs but no other sugars is very limited and it needs further clarification. In such cases, an approach of in silico computer-aided drug design (CADD) might be used to identify potential active drug molecules. Such in silico (computational) studies may be helpful to understand the mode of interaction of $2 \mathrm{dDR}$ with target proteins and to propose some other $2 \mathrm{dDR}$ analogues that could be potential candidates with the potential to stimulate (or inhibit) angiogenesis. This would require a team of synthetic organic chemists, biologists and computational scientists and is beyond our expertise.

\section{The Stability of $2 \mathrm{dDR}$}

One of the disadvantages of peptide growth factors is that they become very unstable when prepared as solutions. VEGF has been reported to lose approximately $60 \%$ and $70 \%$ of its activity over 12 and 30 days, respectively [64]. In the manufacturer's product information sheet (Sigma Aldrich, Cat. No. V7259), it is stated that "reconstituted VEGF can be stored at $2-8{ }^{\circ} \mathrm{C}$ for up to one week".

To assess the stability of $2 \mathrm{dDR}$, only two stability tests have been performed to date in the presence and absence of cells.

In the first study, the stability of the aqueous solution of $2 \mathrm{dDR}$ at room temperature was evaluated by Azam et al. The results demonstrated that $2 \mathrm{dDR}$ was stable with no significant change recorded in the amount of $2 \mathrm{dDR}$ over two weeks [33]. The second experiment was conducted to study the stability of $2 \mathrm{dDR}$ in the presence or absence of HAECs. The results demonstrated that there was a significant decrease in the amount of $2 \mathrm{dDR}$ present in the growth medium over 14 days (both in cellular and acellular conditions) at $37^{\circ} \mathrm{C}$. The decrease in the amount of $2 \mathrm{dDR}$ was higher when HAECs were present. This can be explained by the internalisation of $2 \mathrm{dDR}$ by cells to be used to increase VEGF 
production. By day 14, approximately $40 \%$ and $30 \%$ of the total $2 \mathrm{dDR}$ had disappeared from the growth medium, respectively in the presence and absence of HAECs [32].

2dDR stability in alginate dressings was also evaluated after gamma sterilisation (irradiation dosage of $25 \mathrm{KGy}$ ) by Azam et al. It was noted that 2dDR did not undergo any chemical structural change/decomposition or reaction with alginate dressings due to gamma treatment. Almost all of the 2dDR loaded ( $>90 \%$ ) was released either from gamma sterilised or non-sterilised alginate dressings [33]. Similarly, Andleeb et al. later reported that $2 \mathrm{dDR}$ was stable and gamma sterilisation did not affect its release from cotton dressings [34].

The stability studies of $2 \mathrm{dDR}$ are summarised in Table 1.

Table 1. Summary of 2dDR stability studies.

\begin{tabular}{ccccc}
\hline $\begin{array}{c}\text { 2dDR Was } \\
\text { Prepared in }\end{array}$ & Concentration & $\begin{array}{c}\text { Presence of } \\
\text { Cells }\end{array}$ & $\begin{array}{c}\text { Remaining } \\
\text { 2dDR (\%) }\end{array}$ & Reference \\
\hline Water & $1,2,3 \mathrm{mg} / \mathrm{mL}$ & No & $>95$ & {$[33]$} \\
\hline Growth Medium & $0.135 \mathrm{mg} / \mathrm{mL}$ & No & $>70$ & {$[32]$} \\
\hline Growth Medium & $0.135 \mathrm{mg} / \mathrm{mL}$ & Yes & $>60$ & {$[32]$} \\
\hline
\end{tabular}

\section{The Pro-Angiogenic Potential of 2dDR Compared to VEGF}

VEGF is an established pro-angiogenic factor that has a prime role in inducing angiogenesis [65]. To date, the mechanism of action of VEGF has been studied widely, and we have previously summarised its main pathways that regulate angiogenesis [32]. ECs have been shown to be sensitive to VEGF, and the binding of VEGF to its receptor triggers the cascade that regulates proliferation, migration and survival of ECs $[66,67]$.

VEGF is the gold standard for the induction of vascularisation. However, there are major concerns raised over its safety. The use of exogenous VEGF without controlled delivery systems has been shown to lead to the formation of extremely leaky [61], permeable [62] and haemorrhagic [60] vessels which are associated with tumour development. Please note there is no evidence that VEGF induces tumours but such blood vessels could assist growth and metastasis of existing tumours. Our group alongside many others have developed biomaterials to bind heparin in an attempt to bind and release VEGF in a controlled manner $[55,56]$. However, introducing VEGF to biomaterials requires the use of multistep coating techniques, experienced users and is time-consuming and expensive. Instead of the use of exogenous VEGF, the upregulation of endogenous VEGF production via administration of $2 \mathrm{dDR}$ merits exploration.

In addition to raised concerns over safety, use of exogenous VEGF is a very expensive approach similar to the use of other recombinant growth factors. For instance, when the pro-angiogenic doses were taken as $80 \mathrm{ng} / \mathrm{mL}$ and $134 \mu \mathrm{g} / \mathrm{mL}(1 \mathrm{mM})$, respectively for VEGF (catalogue number: V7259) and 2dDR (catalogue number: 121,649), then 1 L of 2dDR solution at $1 \mathrm{mM}$ is approximately 2000 times less expensive than $1 \mathrm{~L}$ of VEGF solution at $80 \mathrm{ng} / \mathrm{mL}$. These prices were taken from the Sigma Aldrich catalogue.

Accordingly, we asked to what extent did this sugar mimic the biological effects of VEGF.

In 2019, Dikici at al. reported the effects of 2dDR on the proliferation (Figure 5A), migration (Figure 5B) and tube formation (Figure 5C) of HAECs compared to VEGF. The results of this study showed the potential of $2 \mathrm{dDR}$ in increasing the proliferation, migration and branching capability of HAECs being approximately 95\%, 94\%, 87\% as effective as VEGF, respectively [31]. 

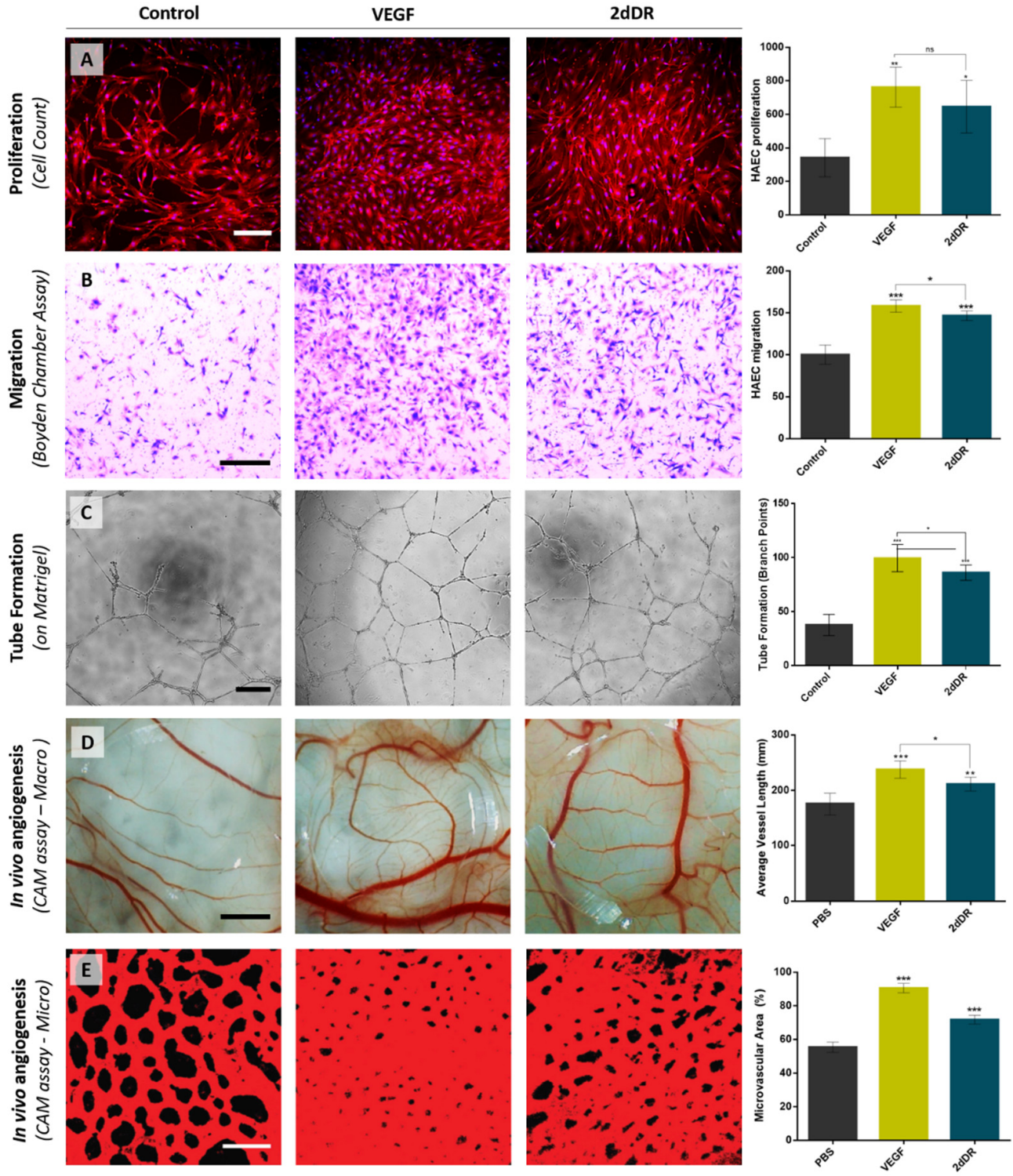

Figure 5. Representative images demonstrating the pro-angiogenic potential of 2dDR compared to VEGF in terms of stimulating the (A) proliferation, (B) migration, (C) tube formation of HAECs, and in vivo angiogenesis assessed by (D) macro vessels and (E) microvasculature in ex ovo CAM bioassay. ( ${ }^{* * *} p \leq 0.001,{ }^{* *} p \leq 0.01,{ }^{*} p \leq 0.05$, ns: not significant, $\mathrm{n}=3$ ). Scale bars represent $200 \mu \mathrm{m}$ for proliferation, $250 \mu \mathrm{m}$ for migration and tube formation images, $2 \mathrm{~mm}$ for macro and $50 \mu \mathrm{m}$ for confocal microvessel images of CAM bioassay. Images, used in (A,D), are adapted from [32] with permission granted by Microvascular Research, Copyright 2020 Elsevier. Images, used in (E), is adapted from [30] with permission granted by Regenerative Medicine, Copyright 2019 Future Medicine.

In 2019, a 2dDR dose study using an in vivo CAM assay was performed with VEGF as positive control. The results demonstrated that treatment with $2 \mathrm{dDR}$ was almost $80 \%$ as effective as VEGF in the stimulation of new blood vessel formation [30].

In 2020, the change in the metabolic activity of HAECs in response to $2 \mathrm{dDR}$ and VEGF treatment was investigated, and 2dDR was found to be approximately $90 \%$ as potent as VEGF in increasing the metabolic activity of HAECs. In the same study, the daily application of $2 \mathrm{dDR}$ solution to CAM augmented the total vessel length, which was roughly $90 \%$ of the effect achieved by VEGF administration (Figure 5D). Similarly, treatment with $2 \mathrm{dDR}$ was found to be approximately $80 \%$ as effective as VEGF in increasing 
the percentage area covered by microvasculature in the drug administration zones on CAM (Figure 5E) [32].

\section{Ongoing Work}

\subsection{2dDR and Skin Microbiology}

When preparing a topical dressing for skin wounds, it is advisable to use components that will not perturb the surrounding skin microbiota or cause a dysbiosis of the microbes either surrounding or within the wound, leading to overgrowth of pathogenic species. Given that $2 \mathrm{dDR}$ is a potential carbohydrate source for bacteria, Yar et al. previously published a pilot study investigating whether two species of bacteria commonly found in chronic skin wounds, Pseudomonas aeruginosa and Staphylococcus aureus, were able to metabolise 2dDR. Of the four strains of S. aureus (S235, NCTC 6571 (Oxford), Newman, and L-9879) and one of P. aeruginosa, none of the S. aureus strains appeared to metabolise the 2dDR (Figure 6A) [29]. Similarly, it has been previously reported that only a very limited number of bacterial species, including Lactobacillus plantarum [68], and Selenomonas ruminantium [69] ferment $2 \mathrm{dDR}$, although these two species should not be a concern for wound dressings as they are not found in skin or in wounds.

\begin{tabular}{|l|c|}
\hline A \\
\hline Bacterial Strain & 2dDR Fermenter? \\
\hline S. aureus S235 & - \\
\hline S. aureus Newman & - \\
\hline S. aureus NCTC 6571 (Oxford) & - \\
\hline S. aureus L-9879 & - \\
\hline P. aeruginosa SOM-1 & + \\
\hline
\end{tabular}

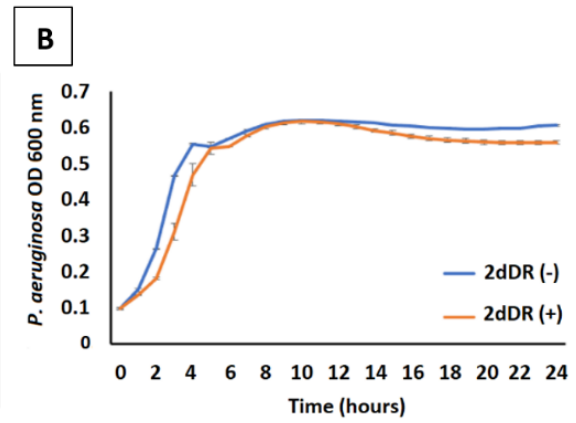

Figure 6. (A) Among the four strains of $S$. aureus tested, none were capable of fermenting 2dDR whilst the P. aeruginosa strain was a fermenter of 2dDR [29]. (B) Growth curves measuring optical density (absorbance at $600 \mathrm{~nm}$ ) of P. aeruginosa SOM-1 over $24 \mathrm{~h}$ in media supplemented with and without $2 \mathrm{dDR}$ reveal that there is no effect of growth of this strain. Error bars represent the SEM $(\mathrm{n}=3)$.

In addition, Escherichia coli and Salmonella enterica are capable of utilising the 2-deoxyd-ribosyl moiety of 2'-deoxyribonucleosides as a carbon source [70]. This limited utilisation of $2 \mathrm{dDR}$ and $2 \mathrm{dDR}$ moieties leads us to believe that a dressing containing $2 \mathrm{dDR}$ ought not to encourage any bacterial growth when applied; however, further studies to investigate this are underway in our laboratories.

As above, a wound dressing ideally should not encourage growth of the microbiota either in an infected wound or on surrounding skin. To that end, experiments are underway in our laboratories to measure the utilisation of a broader range of skin dwelling bacteria and wound pathogens, including Staphylococcus epidermidis, Enterococcus faecalis and the anaerobe Cutibacterium acnes. The response of the bacteria to $2 \mathrm{dDR}$ both as a sole substrate and as released by the dressing is being investigated in mono- and mixed species. To date, addition of $2 \mathrm{dDR}$ to media appears to have either no effect or a negative effect on growth of any species tested (Figure 6B).

\subsection{Stability and Sterilisation}

For sterilisation, our group demonstrated that gamma irradiation was very effective without affecting the stability of $2 \mathrm{dDR}[33,34]$ but further work is ongoing to establish protocols for sterilisation and storage of cotton fibre-based dressing containing $2 \mathrm{dDR}$. 


\section{Conclusions}

First identified in the structure of DNA in the 1930s, and then as a degradation product of it due to TP activity, 2dDR has more recently been investigated as a stimulator of angiogenesis. Other small sugars have been reported to be pro-or anti-angiogenic, and in particular, of the two isomeric forms of this sugar, the D-form appears to be predominantly pro-angiogenic and the L-form to be anti-angiogenic. While it remains difficult to propose any simple structure-activity relationship between these sugars and their angiogenic activity, the biological response to $2 \mathrm{dDR}$ is strong and clearly demonstrable in a series of in vitro and in vivo bioassays, and in animal experiments of cutaneous wound healing.

Incorporation of $2 \mathrm{dDR}$ into a variety of experimental and commercial dressings showed good results in all cases. The sugar can be loaded and released over a few days at a concentration which drives angiogenesis in the CAM bioassay and accelerates wound healing in rats.

Its biological profile mimics that of the addition of VEGF with 2dDR achieving 80$100 \%$ of the biological actions of VEGF. The sugar is more stable and inexpensive than VEGF, and preliminary results suggest that it can be stored in a variety of potential dressings.

We suggest that the addition of $2 \mathrm{dDR}$ to conventional, well-accepted wound dressings may provide a low-cost and simple-to-use pro-angiogenic dressing for use in the treatment of chronic non-healing wounds. This review aims to contribute to the field of angiogenesis by summarising the latest knowledge on a novel pro-angiogenic agent, $2 \mathrm{dDR}$, and introducing it to the scientists working in this field to encourage them to contribute to the further exploration of $2 \mathrm{dDR}$ as a pro-angiogenic agent.

Author Contributions: Literature review, S.D., M.Y., A.J.B., J.S., S.R., S.M.; manuscript draft preparation, S.D.; manuscript writing, review and editing, S.D., M.Y., A.J.B., J.S., S.R., S.M.; supervision, S.M. All authors have read and agreed to the published version of the manuscript.

Funding: We would like to acknowledge COMSATS University Islamabad for funding Muhammad Yar under Pak-UK Fellowship program, during this time was able to start some of this 2dDR work. We thank the Ministry of National Education, the Republic of Turkey for the support of Serkan Dikici who undertook work on $2 \mathrm{dDR}$ as part of his PhD thesis which was awarded by the University of Sheffield in 2020. We thank Cannenta Pty Ltd. (Australia) for funding work in the laboratories of Muhammad Yar and Sheila MacNeil in examining the effect of alginate dressings loaded with $2 \mathrm{dDR}$ in a diabetic rat model. We thank Cotton Craft Pvt Ltd., Pakistan for funding to explore the development of cotton fibre-based dressings loaded with 2dDR. Finally, we are pleased to acknowledge support from the British Council and Higher Education Commission (HEC) Pakistan under Innovative Collaborative Research Grant (ICRG) to support the development of affordable sugar-containing dressing for the treatment of diabetic ulcers and burn injuries in Pakistan.

Acknowledgments: We thank Nicola Burns for technical support in the microbiology experiments.

Conflicts of Interest: The authors declare no conflict of interest.

\section{References}

1. Levene, P.A.; Mikeska, L.A.; Mori, T. On the carbohydrate of thymonucleic acid. J. Biol. Chem. 1930, 85, 785-787. [CrossRef]

2. Frixione, E.; Ruiz-Zamarripa, L. The "scientific catastrophe" in nucleic acids research that boosted molecular biology. J. Biol. Chem. 2019, 294, 2249-2255. [CrossRef] [PubMed]

3. Priestle, J.P.; Paris, C.G. Experimental Techniques and Data Banks. In Guidebook on Molecular Modeling in Drug Design; Academic Press: Cambridge, MA, USA, 1996; pp. 139-217.

4. Desgranges, C.; Razaka, G.; Rabaud, M.; Bricaud, H. Catabolism of thymidine in human blood platelets purification and properties of thymidine phosphorylase. BBA Sect. Nucleic Acids Protein Synth. 1981, 654, 211-218. [CrossRef]

5. Brown, N.S.; Bicknell, R. Thymidine phosphorylase, 2-deoxy-D-ribose and angiogenesis. Biochem. J. 1998, 334, 1-8. [CrossRef]

6. Barton, G.J.; Ponting, C.P.; Spraggon, G.; Finnis, C.; Sleep, D. Human platelet-derived endothelial cell growth factor is homologous to Escherichia coli thymidine phosphorylase. Protein Sci. 1992, 1, 688-690. [CrossRef]

7. Usuki, K.; Saras, J.; Waltenberger, J.; Miyazono, K.; Pierce, G.; Thomason, A.; Heldin, C.H. Platelet-derived endothelial cell growth factor has thymidine phosphorylase activity. Biochem. Biophys. Res. Commun. 1992, 184, 1311-1316. [CrossRef]

8. Friedkin, M.; Roberts, D. The enzymatic synthesis of nucleosides. I. Thymidine phosphorylase in mammalian tissue. J. Biol. Chem. 1954, 207, 245-256. [CrossRef] 
9. Furukawa, T.; Yoshimura, A.; Sumizawa, T.; Haraguchi, M.; Akiyama, S.I.; Fukui, K.; Ishizawa, M.; Yamada, Y. Angiogenic factor. Nature 1992, 356, 668. [CrossRef]

10. Pauly, J.L.; Schuller, M.G.; Zelcer, A.A.; Kirss, T.A.; Gore, S.S.; Germain, M.J. Identification and comparative analysis of thymidine phosphorylase in the plasma of healthy subjects and cancer patients: Brief communication. J. Natl. Cancer Inst. 1977, 58, 1587-1590. [CrossRef] [PubMed]

11. Folkman, J. Tumor Angiogenesis: Therapeutic Implications. N. Engl. J. Med. 1971, 285, 1182-1186.

12. Moghaddam, A.; Zhang, H.T.; Fan, T.P.; Hu, D.E.; Lees, V.C.; Turley, H.; Fox, S.B.; Gatter, K.C.; Harris, A.L.; Bicknell, R. Thymidine phosphorylase is angiogenic and promotes tumor growth. Proc. Natl. Acad. Sci. USA 1995, 92, 998-1002. [CrossRef]

13. Ishikawa, F.; Miyazono, K.; Hellman, U.; Drexler, H.; Wernstedt, C.; Hagiwara, K.; Usuki, K.; Takaku, F.; Risau, W.; Heldin, C.H. Identification of angiogenic activity and the cloning and expression of platelet-derived endothelial cell growth factor. Nature 1989, 338, 557-562. [CrossRef]

14. Miyadera, K.; Sumizawa, T.; Haraguchi, M.; Yoshida, H.; Konstanty, W.; Yamada, Y.; Akiyama, S. Role of thymidine phosphorylase activity in the angiogenic effect of platelet derived endothelial cell growth factor/thymidine phosphorylase. Cancer Res. 1995, 55, 1687-1690. [PubMed]

15. Moghaddam, A.; Choudhuri, R.; Bicknell, R. Thymidine phosphorylase/platelet-derived endothelial cell growth factor: An angiogenic enzyme Tumour Angiogenesis. In Tumour Angiogenesis; Oxford University Press: Oxford, UK, 1997; pp. 251-260.

16. Finnis, C.; Dodsworth, N.; Pollitt, C.E.; Carr, G.; Sleep, D. Thymidine phosphorylase activity of platelet-derived endothelial cell growth factor is responsible for endothelial cell mitogenicity. Eur. J. Biochem. 1993, 212, 201-210. [CrossRef] [PubMed]

17. Sengupta, S.; Sellers, L.A.; Matheson, H.B.; Fan, T.P.D. Thymidine phosphorylase induces angiogenesis in vivo and in vitro: An evaluation of possible mechanisms. Br. J. Pharmacol. 2003, 139, 219-231. [CrossRef] [PubMed]

18. Uchimiya, H.; Furukawa, T.; Okamoto, M.; Nakajima, Y.; Matsushita, S.; Ikeda, R.; Gotanda, T.; Haraguchi, M.; Sumizawa, T.; Ono, M.; et al. Suppression of thymidine phosphorylase-mediated angiogenesis and tumor growth by 2-deoxy-L-ribose. Cancer Res. 2002, 62, 2834-2839.

19. Nakajima, Y.; Madhyastha, R.; Maruyama, M. 2-Deoxy-D-Ribose, a Downstream Mediator of Thymidine Phosphorylase, Regulates Tumor Angiogenesis and Progression. Anticancer. Agents Med. Chem. 2009, 9, 239-245. [CrossRef] [PubMed]

20. Ikeda, R.; Che, X.F.; Ushiyama, M.; Yamaguchi, T.; Okumura, H.; Nakajima, Y.; Takeda, Y.; Shibayama, Y.; Furukawa, T.; Yamamoto, M.; et al. 2-Deoxy-D-ribose inhibits hypoxia-induced apoptosis by suppressing the phosphorylation of p38 MAPK. Biochem. Biophys. Res. Commun. 2006, 342, 280-285. [CrossRef]

21. Nakajima, Y.; Gotanda, T.; Uchimiya, H.; Furukawa, T.; Haraguchi, M.; Ikeda, R.; Sumizawa, T.; Yoshida, H.; Akiyama, S.I. Inhibition of Metastasis of Tumor Cells Overexpressing Thymidine Phosphorylase by 2-Deoxy-L-Ribose. Cancer Res. 2004, 64, 1794-1801. [CrossRef] [PubMed]

22. Ribatti, D. The chick embryo chorioallantoic membrane (CAM) assay. Reprod. Toxicol. 2017, 70, 97-101. [CrossRef] [PubMed]

23. Mangir, N.; Dikici, S.; Claeyssens, F.; MacNeil, S. Using ex Ovo Chick Chorioallantoic Membrane (CAM) Assay to Evaluate the Biocompatibility and Angiogenic Response to Biomaterials. ACS Biomater. Sci. Eng. 2019, 5, 3190-3200. [CrossRef] [PubMed]

24. Aldemir Dikici, B.; Dikici, S.; Reilly, G.C.; MacNeil, S.; Claeyssens, F. A Novel Bilayer Polycaprolactone Membrane for Guided Bone Regeneration: Combining Electrospinning and Emulsion Templating. Materials 2019, 12, 2643. [CrossRef]

25. Dikici, S.; Claeyssens, F.; MacNeil, S. Pre-Seeding of Simple Electrospun Scaffolds with a Combination of Endothelial Cells and Fibroblasts Strongly Promotes Angiogenesis. Tissue Eng. Regen. Med. 2020, 17, 445-458. [CrossRef]

26. Dikici, S.; Claeyssens, F.; MacNeil, S. Decellularised baby spinach leaves and their potential use in tissue engineering applications: Studying and promoting neovascularisation. J. Biomater. Appl. 2019, 34, 546-559. [CrossRef] [PubMed]

27. Dikici, S.; Aldemir Dikici, B.; MacNeil, S.; Claeyssens, F. Decellularised extracellular matrix decorated PCL PolyHIPE scaffolds for enhanced cellular activity, integration and angiogenesis. Biomater. Sci. 2021. Advance Article. [CrossRef]

28. Aldemir Dikici, B.; Reilly, G.C.; Claeyssens, F. Boosting the Osteogenic and Angiogenic Performance of Multiscale Porous Polycaprolactone Scaffolds by in Vitro Generated Extracellular Matrix Decoration. ACS Appl. Mater. Interfaces 2020, 12, 12510-12524. [CrossRef]

29. Yar, M.; Shahzadi, L.; Mehmood, A.; Raheem, M.I.; Román, S.; Chaudhry, A.A.; ur Rehman, I.; Ian Douglas, C.W.; MacNeil, S. Deoxy-sugar releasing biodegradable hydrogels promote angiogenesis and stimulate wound healing. Mater. Today Commun. 2017, 13, 295-305. [CrossRef]

30. Dikici, S.; Mangir, N.; Claeyssens, F.; Yar, M.; MacNeil, S. Exploration of 2-deoxy-D-ribose and 17 $\beta$-Estradiol as alternatives to exogenous VEGF to promote angiogenesis in tissue-engineered constructs. Regen. Med. 2019, 14, 179-197. [CrossRef] [PubMed]

31. Dikici, S.; Aldemir Dikici, B.; Bhaloo, S.I.; Balcells, M.; Edelman, E.R.; MacNeil, S.; Reilly, G.C.; Sherborne, C.; Claeyssens, F. Assessment of the angiogenic potential of 2-deoxy-D-ribose using a novel in vitro 3D dynamic model in comparison with established in vitro assays. Front. Bioeng. Biotechnol. 2019, 7, 451. [CrossRef]

32. Dikici, S.; Bullock, A.J.; Yar, M.; Claeyssens, F.; MacNeil, S. 2-deoxy-D-ribose (2dDR) upregulates vascular endothelial growth factor (VEGF) and stimulates angiogenesis. Microvasc. Res. 2020, 131, 104035. [CrossRef] [PubMed]

33. Azam, M.; Dikici, S.; Roman, S.; Mehmood, A.; Chaudhry, A.A.; U Rehman, I.; MacNeil, S.; Yar, M. Addition of 2-deoxy-d-ribose to clinically used alginate dressings stimulates angiogenesis and accelerates wound healing in diabetic rats. J. Biomater. Appl. 2019, 34, 463-475. [CrossRef] 
34. Andleeb, A.; Dikici, S.; Waris, T.S.; Bashir, M.M.; Akhter, S.; Chaudhry, A.A.; MacNeil, S.; Yar, M. Developing affordable and accessible pro-angiogenic wound dressings; incorporation of 2 deoxy D-ribose (2dDR) into cotton fibres and wax-coated cotton fibres. J. Tissue Eng. Regen. Med. 2020, 14, 973-988. [CrossRef]

35. Haraguchi, M.; Miyadera, K.; Uemura, K.; Sumizawa, T.; Furukawa, T.; Yamada, K.; Akiyama, S.I.; Yamada, Y. Angiogenic activity of enzymes. Nature 1994, 368, 198. [CrossRef]

36. Zhang, H.-T.; Choudhuri, R.; Scott, P.A.; Zhang, L.; Ziche, M.; Morbidelli, L.; Donnini, S.; Jagger, R.T.; Chan, H.-Y.; Smith, K.; et al. Angiogenic Polypeptides in Breast Cancer: Expression of Mrna's in Primary Human Tumours, MCF-7 Cell Transfection and Xenograft Models. In Angiogenesis; Springer: Boston, MA, USA, 1998; pp. 213-221.

37. Nakajima, Y.; Haraguchi, M.; Furukawa, T.; Yamamoto, M.; Nakanishi, H.; Tatematsu, M.; Akiyama, S.I. 2-Deoxy-L-ribose inhibits the invasion of thymidine phosphorylase- overexpressing tumors by suppressing matrix metalloproteinase-9. Int. J. Cancer 2006, 119, 1710-1716. [CrossRef] [PubMed]

38. Vara, D.; Watt, J.M.; Fortunato, T.M.; Mellor, H.; Burgess, M.; Wicks, K.; Mace, K.; Reeksting, S.; Lubben, A.; Wheeler-Jones, C.P.D.; et al. Direct Activation of NADPH Oxidase 2 by 2-Deoxyribose-1-Phosphate Triggers Nuclear Factor Kappa B-Dependent Angiogenesis. Antioxid. Redox Signal. 2018, 28, 110-130. [CrossRef] [PubMed]

39. Dikici, S.; Claeyssens, F.; MacNeil, S. Bioengineering Vascular Networks to Study Angiogenesis and Vascularization of Physiologically Relevant Tissue Models in Vitro. ACS Biomater. Sci. Eng. 2020, 6, 3513-3528. [CrossRef] [PubMed]

40. Ramos-rodriguez, D.H.; MacNeil, S.; Claeyssens, F.; Asencio, I.O. Delivery of bioactive compounds to improve skin cell responses on microfabricated electrospun microenvironments. Bioengineering 2021, 8, 105. [CrossRef]

41. Lemieux, R.U.; Anderson, L.; Conner, A.H. The mutarotation of 2-deoxy- $\beta$-d-erythro-pentose ("2-deoxy- $\beta$-d-ribose"). Conformations, kinetics, and equilibria. Carbohydr. Res. 1971, 20, 59-72. [CrossRef]

42. Fan, C.; Deng, Q.; Zhu, T.F. Bioorthogonal information storage in l-DNA with a high-fidelity mirror-image Pfu DNA polymerase. Nat. Biotechnol. 2021. [CrossRef]

43. Vogel, T.; Blake, D.A.; Whikehart, D.R.; Guo, N.-H.; Zabrenetzky, V.S.; Roberts, D.D. Specific simple sugars promote chemotaxis and chemokinesis of corneal endothelial cells. J. Cell. Physiol. 1993, 157, 359-366. [CrossRef] [PubMed]

44. Shigematsu, S.; Yamauchi, K.; Nakajima, K.; Iijima, S.; Aizawa, T.; Hashizume, K. IGF-1 regulates migration and angiogenesis of human endothelial cells. Endocr. J. 1999, 46, 59-62. [CrossRef]

45. Madonna, R.; Giovannelli, G.; Confalone, P.; Renna, F.V.; Geng, Y.J.; De Caterina, R. High glucose-induced hyperosmolarity contributes to COX-2 expression and angiogenesis: Implications for diabetic retinopathy. Cardiovasc. Diabetol. 2016, 15, 18. [CrossRef]

46. Teixeira, A.S.; Andrade, S.P. Glucose-induced inhibition of angiogenesis in the rat sponge granuloma is prevented by aminoguanidine. Life Sci. 1999, 64, 655-662. [CrossRef]

47. Jiraritthamrong, C.; Kheolamai, P.; U-Pratya, Y.; Chayosumrit, M.; Supokawej, A.; Manochantr, S.; Tantrawatpan, C.; Sritanaudomchai, H.; Issaragrisil, S. In vitro vessel-forming capacity of endothelial progenitor cells in high glucose conditions. Ann. Hematol. 2012, 91, 311-320. [CrossRef]

48. Ikeda, R.; Furukawa, T.; Kitazono, M.; Ishitsuka, K.; Okumura, H.; Tani, A.; Sumizawa, T.; Haraguchi, M.; Komatsu, M.; Uchimiya, H.; et al. Molecular basis for the inhibition of hypoxia-induced apoptosis by 2-deoxy-D-ribose. Biochem. Biophys. Res. Commun. 2002, 291, 806-812. [CrossRef]

49. Tagg, S.L.C.; Foster, P.A.; Leese, M.P.; Potter, B.V.L.; Reed, M.J.; Purohit, A.; Newman, S.P. 2-Methoxyoestradiol-3,17-O,O-bissulphamate and 2-deoxy-D-glucose in combination: A potential treatment for breast and prostate cancer. Br. J. Cancer 2008, 99, 1842-1848. [CrossRef] [PubMed]

50. Merchan, J.R.; Kovács, K.; Railsback, J.W.; Kurtoglu, M.; Jing, Y.; Piña, Y.; Gao, N.; Murray, T.G.; Lehrman, M.A.; Lampidis, T.J. Antiangiogenic activity of 2-deoxy-D-glucose. PLoS ONE 2010, 5, e13699. [CrossRef]

51. Chuang, I.C.; Yang, C.M.; Song, T.Y.; Yang, N.C.; Hu, M.L. The anti-angiogenic action of 2-deoxyglucose involves attenuation of VEGFR2 signaling and MMP-2 expression in HUVECs. Life Sci. 2015, 139, 52-61. [CrossRef] [PubMed]

52. Kovacs, K.; Decatur, C.; Toro, M.; Pham, D.G.; Liu, H.; Jing, Y.; Murray, T.G.; Lampidis, T.J.; Merchan, J.R. 2-deoxy-glucose downregulates endothelial AKT and ERK via interference with N-linked glycosylation, induction of endoplasmic reticulum stress, and GSK3 $\beta$ activation. Mol. Cancer Ther. 2016, 15, 264-275. [CrossRef] [PubMed]

53. Zhang, D.; Fei, Q.; Li, J.; Zhang, C.; Sun, Y.; Zhu, C.; Wang, F.; Sun, Y. 2-Deoxyglucose reverses the promoting effect of insulin on colorectal cancer cells in vitro. PLoS ONE 2016, 11, e0151115. [CrossRef]

54. Singh, S.; Pandey, S.; Chawla, A.S.; Bhatt, A.N.; Roy, B.G.; Saluja, D.; Dwarakanath, B.S. Dietary 2-deoxy-D-glucose impairs tumour growth and metastasis by inhibiting angiogenesis. Eur. J. Cancer 2019, 123, 11-24. [CrossRef]

55. Yar, M.; Gigliobianco, G.; Shahzadi, L.; Dew, L.; Siddiqi, S.A.; Khan, A.F.; Chaudhry, A.A.; Rehman, I.U.; MacNeil, S. Production of chitosan PVA PCL hydrogels to bind heparin and induce angiogenesis. Int. J. Polym. Mater. Polym. Biomater. 2016, 65, 466-476. [CrossRef]

56. Gigliobianco, G.; Chong, C.K.; MacNeil, S. Simple surface coating of electrospun poly-L-lactic acid scaffolds to induce angiogenesis. J. Biomater. Appl. 2015, 30, 50-60. [CrossRef]

57. Mele, E. Electrospinning of natural polymers for advanced wound care: Towards responsive and adaptive dressings. J. Mater. Chem. B 2016, 4, 4801-4812. [CrossRef] [PubMed] 
58. Velnar, T.; Bailey, T.; Smrkolj, V. The wound healing process: An overview of the cellular and molecular mechanisms. J. Int. Med. Res. 2009, 37, 1528-1542. [CrossRef] [PubMed]

59. Han, G.; Ceilley, R. Chronic Wound Healing: A Review of Current Management and Treatments. Adv. Ther. 2017, 34, 599-610. [CrossRef]

60. Cheng, S.Y.; Nagane, M.; Huang, H.S.; Cavenee, W.K. Intracerebral tumor-associated hemorrhage caused by overexpression of the vascular endothelial growth factor isoforms VEGF121 and VEGF165 but not VEGF189. Proc. Natl. Acad. Sci. USA 1997, 94, 12081-12087. [CrossRef] [PubMed]

61. Yancopoulos, G.D.; Davis, S.; Gale, N.W.; Rudge, J.S.; Wiegand, S.J.; Holash, J. Vascular-specific growth factors and blood vessel formation. Nature 2000, 407, 242-248. [CrossRef] [PubMed]

62. Cao, R.; Eriksson, A.; Kubo, H.; Alitalo, K.; Cao, Y.; Thyberg, J. Comparative Evaluation of FGF-2-, VEGF-A-, and VEGF-C-Induced Angiogenesis Lymphangiogenesis, Vascular Fenestrations, and Permeability. Circ. Res. 2004, 94, 664-670. [CrossRef]

63. Oka, N.; Soeda, A.; Inagaki, A.; Onodera, M.; Maruyama, H.; Hara, A.; Kunisada, T.; Mori, H.; Iwama, T. VEGF promotes tumorigenesis and angiogenesis of human glioblastoma stem cells. Biochem. Biophys. Res. Commun. 2007, 360, 553-559. [CrossRef]

64. Mizumachi, H.; Ijima, H. Measuring Stability of Vascular Endothelial Growth Factor using an Immobilization Technique. Adv. Biomed. Eng. 2013, 2, 130-136. [CrossRef]

65. Hoeben, A.N.N.; Landuyt, B.; Highley, M.S.M.; Wildiers, H.; Oosterom, A.T.V.A.N.; Bruijn, E.A.D.E.; Van Oosterom, A.T.; De Bruijn, E.A. Vascular endothelial growth factor and angiogenesis. Pharmacol. Rev. 2004, 56, 549-580. [CrossRef] [PubMed]

66. Olsson, A.K.; Dimberg, A.; Kreuger, J.; Claesson-Welsh, L. VEGF receptor signalling-In control of vascular function. Nat. Rev. Mol. Cell Biol. 2006, 7, 359-371. [CrossRef]

67. Wang, S.; Li, X.; Parra, M.; Verdin, E.; Bassel-Duby, R.; Olson, E.N. Control of endothelial cell proliferation and migration by VEGF signaling to histone deacetylase 7. Proc. Natl. Acad. Sci. USA 2008, 105, 7738-7743. [CrossRef]

68. Domagk, G.F.; Horecker, B.L. Pentose fermentation by Lactobacillus plantarum. V. Fermentation of 2-deoxy-D-ribose. J. Biol. Chem. 1958, 233, 283-286. [CrossRef]

69. Rasmussen, M.A. Isolation and characterization of Selenomonas ruminantium strains capable of 2-deoxyribose utilization. Appl. Environ. Microbiol. 1993, 59, 2077-2081. [CrossRef] [PubMed]

70. Christensen, M.; Borza, T.; Dandanell, G.; Gilles, A.M.; Barzu, O.; Kelln, R.A.; Neuhard, J. Regulation of expression of the 2-deoxy-D-ribose utilization regulon, deoQKPX, from Salmonella enterica serovar Typhimurium. J. Bacteriol. 2003, 185, 6042-6050. [CrossRef] 